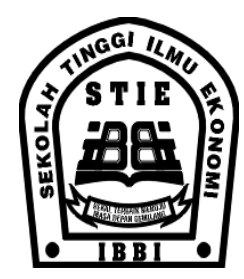

ISSN 1858-3199

JURNAL

MANAJEMEN BISNIS

STIE IBBI

\title{
ANALISIS PENGARUH LINGKUNGAN KERJA DAN DISIPLIN KERJA KARYAWAN TERHADAP PENINGKATAN KINERJA KARYAWAN PT. PERKEBUNAN NUSANTARA II UNIT HELVETIA MEDAN
}

\author{
Junaidi Hasan ${ }^{1}$ Hamdani $^{2}$
}

\begin{abstract}
ABSTRAK
Dalam mengantisipasi ketertinggalan dan memperoleh kemajuan yang signifikan, perusahaan memerlukan kinerja yang baik dari setiap karyawannya. Dengan adanya kinerja yang baik, maka setiap karyawan akan dapat menyelesaikan segala beban pekerjaan dengan efisien dan efektif. Diduga faktor lingkungan kerja serta disiplin kerja yang baik mampu meningkatkan kinerja karyawan.

Penelitian ini menganalisis pengaruh lingkungan kerja dan disiplin kerja karyawan terhadap peningkatan kinerja karyawan. Analisis data dengan menggunakan uji regresi linier berganda, dimana variabel dependen (Y) yaitu peningkatan kinerja karyawan, sedangkan variabel independen $(\mathrm{X})$ adalah lingkungan kerja, dan disiplin kerja karyawan. Jumlah populasi dalam penelitian ini sebanyak 39 orang, dan seluruhnya dijadikan sampel. Pengolahan data dilakukan dengan menggunakan bantuan komputer program SPSS versi 17.0.

Hasil penelitian menunjukkan bahwa lingkungan kerja berpengaruh positif terhadap kinerja karyawan PT. Perkebunan Nusantara II Unit Helvetia Medan, $\mathrm{t}_{\text {hitung }}(2,687)$ dan nilai $p=0,011$. Disiplin kerja berpengaruh positif terhadap kinerja karyawan PT. Perkebunan Nusantara II Unit Helvetia Medan, $t_{\text {hitung }}(2,947)$ dan nilai $p=0,006$. Variabel lingkungan kerja dan disiplin kerja dapat menjelaskan kinerja karyawan sebesar 54,1\%, sedangkan sisanya sebesar $45,9 \%$ dipengaruhi oleh variabel lain yang tidak diteliti.

Kesimpulan penelitian ini bahwa lingkungan kerja dan disiplin kerja karyawan berpengaruh terhadap kinerja karyawan. Semakin baik lingkungan kerja dan disiplin kerja karyawan maka akan semakin meningkat pula kinerja karyawan PT. Perkebunan Nusantara II Unit Helvetia Medan.
\end{abstract}

Kata Kunci: Lingkungan Kerja, Disiplin Kerja, Kinerja Karyawan 


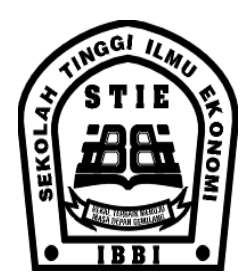

\section{PENDAHULUAN}

Karyawan merupakan sumber daya manusia yang terlibat langsung dalam menjalankan aktivitas perusahaan. Dalam melaksanakan aktivitas perusahaan, karyawan tidak terlepas dari lingkungan kerja. Lingkungan kerja di dalam perusahaan sangat penting diperhatikan oleh manajemen perusahaan, sebab sebuah program untuk meningkatkan kinerja karyawan tidak dapat dilaksanakan dengan efektif apabila tidak didukung dengan lingkungan kerja yang baik, yang ditandai dengan baiknya sirkulasi udara yang cukup, penerangan lampu yang terang dan jauh dari kebisingan suara yang mengganggu konsentrasi kerja, tata ruang yang baik dan warna yang indah serta kebersihan yang terjaga sehingga membuat karyawan tetap bekerja.

Ketenangan karyawan dalam menjalankan aktivitasnya merupakan suatu kondisi positif dalam pekerjaan, yang dapat mendukung terciptanya kinerja yang tinggi sehingga pelaksanaan kegiatan di dalam perusahaan dapat berjalan dengan baik. Lingkungan kerja dalam suatu perusahaan sangat penting untuk diperhatikan manajemen. Meskipun lingkungan kerja tidak melaksanakan aktivitas dalam suatu perusahaan, namun lingkungan kerja mempunyai pengaruh langsung terhadap karyawan yang melaksanakan aktivitas tersebut. Lingkungan kerja dapat meningkatkan kinerja dan sebaliknya lingkungan kerja yang tidak baik dapat menurunkan kinerja karyawan.

Selain lingkungan kerja, karyawan akan dapat meningkatkan kinerja kerjanya apabila memiliki disiplin yang baik dalam pelaksanaan kerjanya. Disiplin kerja karyawan yang baik sangat diharapkan oleh perusahaan dalam merealisasikan tujuan perusahaan, baik tujuan jangka pendek maupun tujuan jangka panjang. Bagi perusahaan, disiplin kerja akan menjamin terpeliharanya tata tertib dan kelancaran pelaksanaan tugas sehingga diperoleh hasil yang optimal. Bagi karyawan, dengan adanya disiplin kerja akan diperoleh suasana kerja yang menyenangkan sehingga akan menambah semangat kerja dalam melaksanakan pekerjaannya dan kinerja kerja yang tinggi yang diharapkan perusahaan dapat tercapai karena setiap pekerjaan yang dibebankan kepada karyawan dapat diselesaikan dengan baik dan tepat waktunya.

Setiap perusahaan selalu berkeinginan agar tenaga kerja yang dimilikinya, mampu memberikan kinerja kerja yang tinggi. Begitu juga dengan PT. Perkebunan Nusantara II Unit Helvetia Medan, sebagai salah satu perusahaan milik negara memiliki tujuan untuk memajukan perusahaan dengan menghasilkan produk yang berkualitas. Oleh karena itu, perusahaan membutuhkan karyawan yang memiliki kinerja yang tinggi di dalam menghasilkan produk yang mampu memenuhi kebutuhan konsumen dan mampu bersaing dengan perusahaan lain sejenis.

Pengamatan pra penelitian para PT. Perkebunan Nusantara II Unit Helvetia Medan II Unit Helvetia Medan menunjukkan beberapa permasalahan yang dihadapi karyawan pada lingkungan kerjanya adalah suhu udara di ruang kerja yang dirasakan kurang sejuk, bahkan terkadang terasa panas karena minimnya ventilasi udara dan sistim pendingin ruangan yang tidak berfungsi dengan baik. Selain itu, ruang gerak yang minim di dalam ruangan kerja karena banyak dokumen dan arsip yang menumpuk di sekitar meja kerja sehingga membuat karyawan tidak leluasa dalam bekerja.

Dalam hal disiplin kerja, masih banyak karyawan PT. Perkebunan Nusantara II Unit Helvetia Medan II Unit Helvetia Medan yang kurang disiplin di dalam pelaksanaan tugas sehari-hari. Hal ini tercermin dari tingkat kehadiran karyawan di kantor setiap harinya, seperti tidak tepat waktu saat masuk kantor, menunda tugas kantor dan bahkan ada karyawan yang meninggalkan tugas pada jam kerja tanpa keterangan yang sah.

\section{KAJIAN LITERATUR}

\section{Lingkungan Kerja}

Lingkungan kerja yang baik akan memberikan kenyamanan pribadi maupun di dalam membangkitkan semangat kerja karyawan sehingga 


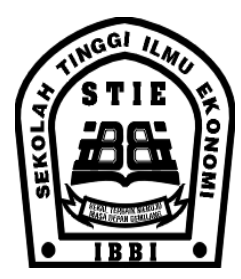

dapat mengerjakan tugas-tugas dengan baik. Selain itu, karyawan akan lebih senang dan nyaman dalam bekerja apabila fasilitas yang ada dalam keadaan bersih, tidak bising, pertukaran udara yang cukup baik dan peralatan yang memadai serta relatif modern. Cikmat dalam Nawawi (2003:292) mengemukakan bahwa, "Lingkungan kerja adalah serangkaian sifat kondisi kerja yang dapat diukur berdasarkan persepsi bersama dari para anggota organisasi yang hidup dan bekerjasama dalam suatu organisasi".

Baik buruknya lingkungan kerja harus diukur dengan menggunakan suatu indikator penilaian. Berdasarkan faktor-faktor yang dikemukakan Sedarmayanti (2009:28-35), maka indikator yang akan digunakan untuk mengukur lingkungan kerja terdiri dari :

1. Penerangan

2. Temperatur

3. Sirkulasi Udara

4. Kebisingan

5. Tata warna Keamanan di tempat kerja

\section{Disiplin Kerja}

Menurut Terry dalam Sutrisno (2010:87). "Disiplin merupakan alat penggerak karyawan. Agar tiap pekerjaan dapat berjalan dengan lancar, maka harus diusahakan agar ada disiplin yang baik. Disiplin tidak hanya dihubungkan dengan hal-hal yang kurang menyenangkan (hukuman) karena sebenarnya hukuman merupakan alat paling akhir untuk menegakkan disiplin". Fathoni (2006:126) mengemukakan bahwa, "Kedisiplinan adalah kesadaran dan kesediaan seseorang menaati semua peraturan perusahaan dan norma-norma sosial yang berlaku".

Menurut Dharmawan (2011:74-75), indikator yang dapat digunakan untuk mengukur disiplin kerja karyawan terdiri dari :

1. Absensi/kehadiran

Sikap dan kemampuan karyawan untuk hadir dan meninggalkan kantor tepat pada waktunya.

2. Ketaatan pada kewajiban tugas dan peraturan Kemampuan karyawan untuk mengikuti instruksi kerja dan bertanggung jawab terhadap pekerjaan yang dilaksanakan.

3. Bekerja sesuai prosedur

\section{ISSN 1858-3199 \\ JURNAL \\ MANAJEMEN BISNIS \\ STIE IBBI}

Kemampuan karyawan untuk mengikuti prosedur kerja yang ditetapkan perusahaan dan menciptakan suasana kerja yang baik di dalam perusahaan.

\section{Kinerja}

Menurut Mangkunegara dalam Riani (2011:98),

"Kinerja adalah hasil kerja secara kualitas dan kuantitas yang dicapai oleh seseorang karyawan dalam melaksanakan tugasnya sesuai dengan tanggung jawab yang diberikan kepadanya". Rivai dan Basri dalam Kaswan (2012:187) mengemukakan bahwa, "Kinerja adalah hasil atau tingkat keberhasilan seseorang secara keseluruhan selama periode tertentu di dalam melaksanakan tugas dibandingkan dengan berbagai kemungkinan, seperti standar hasil kerja, target atau sasaran, atau kriteria yang telah ditentukan terlebih dahulu dan telah disepakati bersama".

Menurut Bernandin \& Russell dalam Riani (2011:99), indikator ukuran kinerja yang dapat digunakan sebagai dasar untuk menilai kinerja terdiri dari :

1. Quality of Work (kuantitas kerja)

Jumlah kerja yang dilakukan dalam suatu periode yang ditentukan.

2. Quality of Work (kualitas kerja)

Kualitas kerja yang dicapai berdasarkan syaratsyarat kesesuaian dan kesiapannya.

3. Job Knowledge (pengetahuan kerja)

Luasnya pengetahuan mengenai pekerjaan dan keterampilannya.

4. Creativeness (kreativitas)

Keaslian gagasan yang dimunculkan dan tindakan-tindakan untuk menyelesaikan persoalan-persoalan yang timbul.

5. Cooperation (kerjasama)

Kesediaan untuk bekerja sama dengan orang lain atau sesama anggota organisasi.

6. Initiative (inisiatif)

Semangat untuk melaksanakan tugas-tugas baru dan dalam memperbesar tanggung jawabnya. 


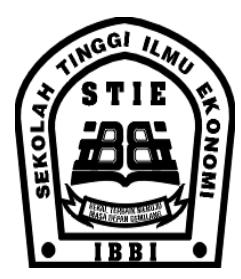

\section{METODE PENELITIAN}

Jenis penelitian yang dilakukan adalah penelitian deskriptif kuantitatif. Penelitian dilakukan di PT. Perkebunan Nusantara II Unit Helvetia Medan. Populasi penelitian adalah seluruh pegawai di PT. Perkebunan Nusantara II Unit Helvetia Medan berjumlah 39 orang. Arikunto (2006:134) mengemukakan apabila jumlah populasi kurang dari 100 orang maka diambil keseluruhannya sehingga penelitian merupakan penelitian populasi.

Data yang digunakan dalam penelitian ini yakni: data primer yang diperoleh di dalam penelitian langsung ke lapangan dan data sekunder yang diperoleh dengan membaca buku-buku yang ada hubungannya dengan judul penelitian ini. Teknik pengumpulan data yang digunakan dalam penelitian ini menggunakan data primer dan data sekunder.

Metode analisis data yang digunakan dalam penelitian ini adalah:

1. Analisis regresi linier berganda

Alat uji yang dipergunakan untuk menganalisis hipotesis dalam penelitian ini adalah Analisis Regresi Linier Berganda. Analisis regresi linier berganda dipergunakan karena variabel terikat yang dicari dipengaruhi oleh dua atau lebih variabel bebas.

Regresi linier berganda menggunakan model persamaan sebagai berikut:

$$
\mathbf{Y}=\mathbf{a}+\mathbf{b}_{1} \mathbf{X}_{1}+\mathbf{b}_{2} \mathbf{X}_{2}+\mathbf{e}
$$

dimana :

$\mathrm{Y}=$ Kinerja

$\mathrm{a}=$ Konstanta

$\mathrm{b}=$ Koefisien Regresi

$\mathrm{X}_{1}=$ Lingkungan kerja

$\mathrm{X}_{2}=$ Disiplin kerja

e $\quad=$ Tingkat kesalahan (Error of Term)

2. Uji Koefisien Determinasi $\left(\mathrm{R}^{2}\right)$

Identifikasi koefisien determinasi ditujukan untuk mengetahui seberapa besar kemampuan model dalam menerangkan variabel terikat. Jika koefisien determinasi $\left(\mathrm{R}^{2}\right)$ semakin besar atau mendekati 1, maka dapat dikatakan bahwa

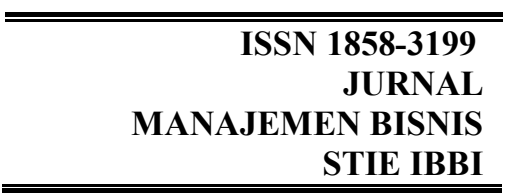

kemampuan variabel bebas (X) adalah besar terhadap variabel terikat (Y).

3. Uji Signifikansi Simultan (Uji F)

Uji $\mathrm{F}$ digunakan untuk menunjukkan apakah semua variabel independen yang dimasukkan dalam model mempunyai pengaruh secara bersama-sama terhadap variabel dependen.

4. Uji Signifikansi Parsial (Uji t)

Uji t digunakan untuk menunjukkan seberapa besar pengaruh satu variabel independen terhadap variabel dependen.

\section{HASIL DAN PEMBAHASAN}

\section{Karakteristik Responden}

Identitas responden yang ditanyakan pada responden yaitu umur, jenis kelamin, status, pendidikan terakhir, dan lama bekerja.

Tabel 1. Identitas Responden

\begin{tabular}{|c|c|c|c|}
\hline No & Identitas Responden & $\mathrm{f}$ & $(\%)$ \\
\hline & Umur: & & \\
\hline 1 & 20-30 tahun & 2 & 5,1 \\
\hline 2 & 31-40 tahun & 7 & 17,9 \\
\hline 3 & 41-50 tahun & 25 & 64,1 \\
\hline 4 & $>50$ tahun & 5 & 12,9 \\
\hline \multicolumn{2}{|r|}{ Jumlah } & 39 & 100,0 \\
\hline 1 & $\begin{array}{l}\text { Jenis Kelamin: } \\
\text { Laki-laki }\end{array}$ & 18 & 46,2 \\
\hline 2 & Perempuan & 21 & 53,8 \\
\hline \multicolumn{2}{|r|}{ Jumlah } & 39 & 100,0 \\
\hline & Status: & & \\
\hline 1 & Lajang & 4 & 10,3 \\
\hline 2 & Menikah & 30 & 76,9 \\
\hline 3 & Janda & 2 & 5,1 \\
\hline 4 & Duda & 3 & 7,7 \\
\hline \multicolumn{2}{|r|}{ Jumlah } & 39 & 100,0 \\
\hline & Pendidikan : & & \\
\hline 1 & SMA & 21 & 53,8 \\
\hline 2 & Diploma & 11 & 28,3 \\
\hline 3 & Sarjana & 7 & 17,9 \\
\hline \multicolumn{2}{|r|}{ Jumlah } & 39 & 100,0 \\
\hline 1 & $\begin{array}{l}\text { Lama Bekerja: } \\
\leq 10 \text { tahun }\end{array}$ & 2 & 5,1 \\
\hline
\end{tabular}




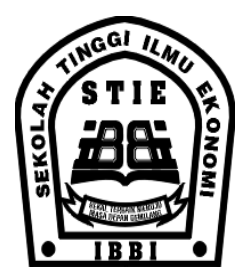

\begin{tabular}{|c|l|l|r|}
\hline No & Identitas Responden & \multicolumn{1}{c|}{$\mathrm{f}$} & \multicolumn{1}{c|}{$(\%)$} \\
\hline 2 & $11-20$ tahun & 21 & 53,8 \\
3 & $21-30$ tahun & 16 & 41,1 \\
\hline \multicolumn{2}{|c|}{ Jumlah } & 39 & 100,0 \\
\hline
\end{tabular}

Sumber: Hasil Penelitian, 2013 (Data diolah)

Tabel di atas menunjukkan bahwa sebagian besar responden berumur 41-50 tahun sebanyak 25 orang $(64,1 \%)$, berjenis kelamin perempuan sebanyak 21 orang $(53,8 \%)$, status perkawinan yaitu menikah sebanyak 30 orang $(76,9 \%)$, pendidikan terakhir SMA yaitu 21 orang $(53,8 \%)$, dan telah bekerja antara 11-20 tahun yaitu 21 orang $(41,0 \%)$.

\section{Uji Kualitas Data}

\section{a. Uji Validitas}

Nilai r-hitung dapat dilihat pada kolom corrected item-total correlation. Hasil uji validitas pada 30 orang terhadap 18 butir pertanyaan (lingkungan kerja, disiplin kerja, dan kinerja) menunjukkan bahwa seluruh butir soal dinyatakan valid karena memiliki nilai r-hitung > r-tabel $(0,361)$.

\section{b. Uji Reliabilitas}

Hasil uji reliabilitas kuesioner menunjukkan bahwa nilai Cronbach Alpha hitung memiliki nilai yang lebih tinggi dibandingkan batas ketentuan nilai Cronbach Alpha yaitu 0,600 yaitu lingkungan kerja 0,810 , disiplin kerja 0,822 , dan kinerja 0,829 , dan hasil tersebut menunjukkan bahwa ketiga variabel dinyatakan reliabel (handal).

\section{Uji Asumsi Klasik}

\section{a. Uji Normalitas}

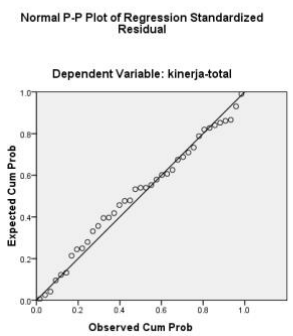

\section{Gambar 1. Grafik P-P Plot}

Pada Gambar 1. Grafik P-P Plot dapat dilihat bahwa data menyebar di sekitar garis diagonal
ISSN 1858-3199

JURNAL

MANAJEMEN BISNIS

STIE IBBI

dan mengikuti arah garis diagonal, jadi disimpulkan bahwa data residual berdistribusi normal maka model regresi memenuhi asumsi normalitas.

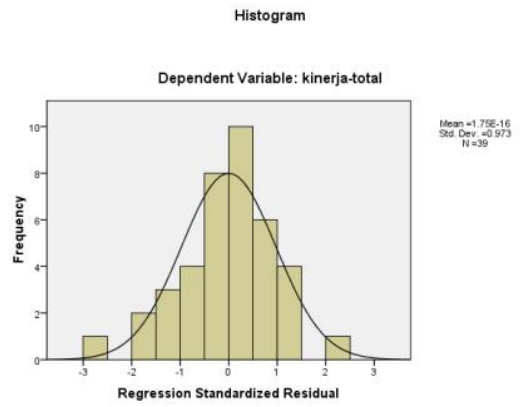

\section{Gambar 2. Histogram Normalitas}

Pada Gambar 2. terlihat bahwa data juga data berdistribusi normal, ini dapat dilihat pada histogram yang menunjukkan bahwa data memiliki bentuk kurva dengan kemiringan seimbang sisi kiri dan kanan, atau tidak condong ke kiri maupun ke kanan, melainkan ke tengah dengan bentuk seperti lonceng.

1) Analisis Kolmogorov-Smirnov

Pengujian normalitas dilakukan berdasarkan uji statistik non-parametrik Kolmogorov-Smirnov (K-S). Menurut Nugroho (2005:112) dasar pengambilan keputusan untuk KolmogorvSmirnov yaitu nilai value pada kolom Asymp. Sig. (2-tailed) $>$ level of significant ( $\square=5 \%$ ).

Tabel 2.

One-Sample Kolmogorov-Smirnov Test Tests of Normality

\begin{tabular}{|c|c|c|c|c|c|c|}
\hline & \multicolumn{3}{|c|}{$\begin{array}{l}\text { Kolmogorov- } \\
\text { Smirnov }^{\mathrm{a}}\end{array}$} & \multicolumn{3}{|c|}{ Shapiro-Wilk } \\
\hline & $\begin{array}{c}\text { Statisti } \\
\text { c }\end{array}$ & df & Sig. & $\begin{array}{c}\text { Statisti } \\
\text { c }\end{array}$ & df & \\
\hline $\begin{array}{l}\text { lingkungan } \\
\text { kerja }\end{array}$ & .109 & 39 & .200 & .958 & 39 & \\
\hline disiplin kerja & .127 & 39 & .113 & .969 & 39 & .3 \\
\hline kinerja & .099 & 39 & $.200^{*}$ & .975 & 39 & .52 \\
\hline
\end{tabular}




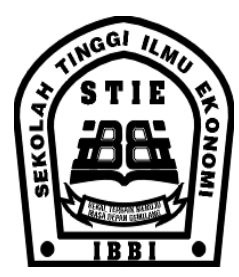

a. Lilliefors Significance Correction

*. This is a lower bound of the true significance.

Berdasarkan pengolahan data pada Tabel 2 . diperoleh nilai pada kolom KolmogorovSmirnov bahwa nilai signifikansi untuk lingkungan kerja 0,200, disiplin kerja 0,113, dan kinerja 0,200. Karena signifikansi untuk seluruh variabel lebih besar dari 0,05 $(>0,05)$ maka dapat disimpulkan bahwa data pada variabel yang diteliti berdistribusi normal.

\section{b. Uji Multikolinieritas}

Uji ini bertujuan untuk menguji apakah di dalam model regresi linier ditemukan adanya korelasi yang tinggi di antara variabel bebas. Menurut Nugroho (2005:58) untuk menguji apakah variabel terkena multikolinieritas atau tidak maka nilai Variance Inflation Factor $(V I F)<5$ dan nilai Tolerance $>0,1$. Hasil uji multikolinieritas dapat dilihat pada tabel berikut.

\section{Tabel 3. Uji Multikolinieritas}

\section{Coefficients $^{\mathrm{a}}$}

\begin{tabular}{|c|c|c|c|c|c|c|c|}
\hline \multirow[b]{2}{*}{ Model } & \multicolumn{2}{|c|}{$\begin{array}{l}\text { Unstandar } \\
\text { dized } \\
\text { Coefficien } \\
\text { ts }\end{array}$} & \multirow{2}{*}{$\begin{array}{l}\text { Standa } \\
\text { rdized } \\
\text { Coeffi } \\
\text { cients }\end{array}$} & \multirow[b]{2}{*}{$\mathrm{t}$} & \multirow[b]{2}{*}{ Sig. } & \multicolumn{2}{|c|}{$\begin{array}{c}\text { Collineari } \\
\text { ty } \\
\text { Statistics }\end{array}$} \\
\hline & B & $\begin{array}{l}\text { Std. } \\
\text { Error }\end{array}$ & & & & $\begin{array}{l}\text { Toler } \\
\text { ance }\end{array}$ & VIF \\
\hline $1 \quad$ (Constant & $\begin{array}{r}1.2 \\
10\end{array}$ & 3.338 & & $\begin{array}{r}.36 \\
2\end{array}$ & $\begin{array}{r}.71 \\
9\end{array}$ & & \\
\hline $\begin{array}{l}\text { lingkung } \\
\text { an kerja }\end{array}$ & $\begin{array}{r}.37 \\
8\end{array}$ & .181 & .297 & $\begin{array}{r}2.0 \\
82\end{array}$ & $\begin{array}{r}.04 \\
5\end{array}$ & .620 & $\begin{array}{r}1.6 \\
12\end{array}$ \\
\hline $\begin{array}{l}\text { disiplin } \\
\text { kerja }\end{array}$ & $\begin{array}{r}.60 \\
1\end{array}$ & .165 & .519 & $\begin{array}{r}3.6 \\
42\end{array}$ & $\begin{array}{r}.00 \\
1\end{array}$ & .620 & $\begin{array}{r}1.6 \\
12\end{array}$ \\
\hline
\end{tabular}

a. Dependent Variable: kinerja

Pada tabel 3. dapat dilihat bahwa nilai Tolerance $>0,1$ dan nilai VIF yaitu $1,612<5$ dengan demikian dapat disimpulkan bahwa model regresi bebas gangguan multi-kolinieritas.

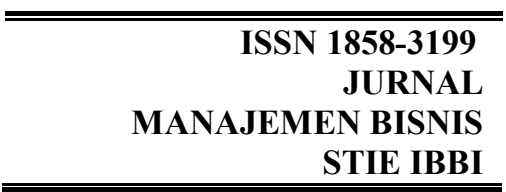

\section{c. Uji Heteroskedastisitas}

Uji heteroskedastisitas digunakan untuk mengetahui ada atau tidaknya penyimpangan asumsi klasik heteroskedastisitas yaitu adanya ketidaksamaan varian dari residual untuk semua pengamatan pada model regresi. Prasyarat yang harus terpenuhi dalam model regresi adalah tidak adanya gejala heteroskedastisitas.

\section{Tabel 4. Hasil Uji Heteroskedastisitas}

\section{Coefficients}

\begin{tabular}{|c|c|c|c|c|c|}
\hline \multirow[b]{2}{*}{ Model } & \multicolumn{2}{|c|}{$\begin{array}{l}\text { Unstandard } \\
\text { ized } \\
\text { Coefficient } \\
\text { s }\end{array}$} & \multirow{2}{*}{ 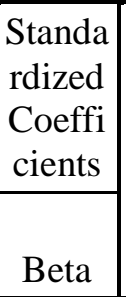 } & \multirow[b]{2}{*}{$\mathrm{t}$} & \multirow[b]{2}{*}{ Sig. } \\
\hline & B & $\begin{array}{l}\text { Std. } \\
\text { Error }\end{array}$ & & & \\
\hline 1 (Constant) & 5.838 & 2.014 & & 2.8 & .006 \\
\hline $\begin{array}{l}\text { lingkunga } \\
\mathrm{n} \text { kerja }\end{array}$ & .100 & .109 & .174 & $\begin{array}{r}91 \\
8\end{array}$ & .365 \\
\hline $\begin{array}{l}\text { disiplin } \\
\text { kerja }\end{array}$ & .034 & .102 & .076 & $\begin{array}{r}.33 \\
7\end{array}$ & .738 \\
\hline
\end{tabular}

a. Dependent Variable: ABS_RES

Dari hasil uji heteroskedastisitas metode gletsjer diperoleh nilai signifikansi variabel lingkungan kerja sebesar $0,365>0,05$, variabel disiplin kerja sebesar 0,738>0,05. Hasil tersebut menunjukkan bahwa nilai signifikansi masingmasing variabel tidak signifikan atau lebih besar dibandingkan dengan derajat signifikansi $\alpha=5 \%(\alpha$ $=0,05)$, dengan demikian model tidak terjadi heteroskedastisitas.

\section{Pengujian Hipotesis}

a. Analisis Regresi Linier Berganda

Berdasarkan hasil uji regresi linier berganda menunjukkan bahwa kedua variabel independen yang diteliti berpengaruh signifikan terhadap kinerja karyawan PTPN II Unit Helvetia Medan yaitu lingkungan kerja dan disiplin kerja karena nilai signifikan <0,05. Pada kolom Unstandardized 


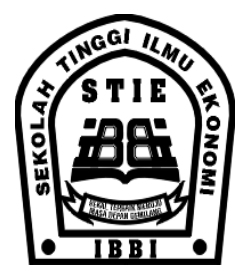

Coefficient bagian B, diperoleh persamaan regresi linier bergandanya adalah sebagai berikut:

$$
Y=0,518+0,511 X_{1}+0,463 X_{2}+e
$$

Berdasarkan persamaan tersebut dapat digambarkan sebagai berikut:

1) Konstanta (a) $=0,518$. Ini mempunyai arti bahwa variabel lingkungan kerja dan disiplin kerja dianggap konstan maka kinerja karyawan (Y) sebesar 0,518.

2) Koefisien $X_{1}\left(b_{1}\right)=0,511$. Variabel lingkungan kerja terhadap kinerja karyawan dengan koefisien regresi sebesar 0,511, artinya bahwa setiap terjadi kenaikan lingkungan kerja sebesar 1 satuan, maka kinerja karyawan akan meningkat sebesar 0,511 .

3) Koefisien $\mathrm{X}_{2}\left(\mathrm{~b}_{2}\right)=0,463$. Variabel disiplin kerja terhadap kinerja karyawan dengan koefisien regresi sebesar 0,511, artinya bahwa setiap terjadi kenaikan disiplin kerja sebesar 1 satuan, maka kinerja karyawan akan meningkat sebesar 0,511 .

\section{b. Uji Koefisien Determinasi $\left(\mathbf{R}^{\mathbf{2}}\right)$}

Analisis determinasi dalam regresi linier berganda digunakan untuk mengetahui persentase sumbangan pengaruh variabel bebas secara serentak terhadap variabel dependen.

\section{Tabel 5. Uji Koefisien Determinasi $\left(\mathbf{R}^{2}\right)$}

Model Summary
\begin{tabular}{|l|l|r|r|r|}
\hline $\begin{array}{l}\text { Mod } \\
\text { el }\end{array}$ & R & $\begin{array}{c}\text { R } \\
\text { Square }\end{array}$ & $\begin{array}{c}\text { Adjusted } \\
\text { R Square }\end{array}$ & $\begin{array}{c}\text { Std. Error } \\
\text { of the } \\
\text { Estimate }\end{array}$ \\
\hline 1 & .736 & .541 & .516 & 2.682 \\
\hline
\end{tabular}

a. Predictors: (Constant), disiplin kerja-total, lingkungan kerja-total

Berdasarkan Tabel 5. di atas diperoleh nilai $\mathrm{R}^{2}$ ( $R$ Square) sebesar 0,541, hal ini berarti bahwa persentase sumbangan pengaruh variabel lingkungan kerja dan disiplin kerja terhadap kinerja karyawan sebesar $54,1 \%$, sedangkan sisanya sebesar $45,9 \%$

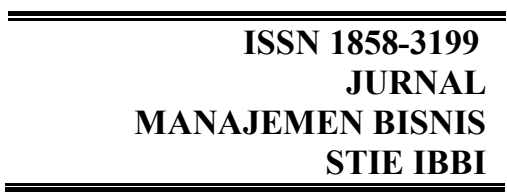

dipengaruhi oleh variabel lain yang tidak diteliti dalam penelitian ini seperti gaya kepemimpinan, supervisi, motivasi, kompensasi, dan lain-lain.

\section{c. Uji F (Uji Simultan / Serentak)}

Uji f (uji simultan/serentak) dilakukan untuk melihat secara bersama-sama pengaruh variabel bebas terhadap variabel terikat (Y). Model hipotesis yang digunakan dalam uji $\mathrm{F}$ ini adalah sebagai berikut:

Ho : $b_{1}=b_{2}=0$, artinya secara serentak tidak terdapat pengaruh positif dan signifikan dari variabel bebas $\left(\mathrm{X}_{1}, \mathrm{X}_{2}\right)$ berupa lingkungan kerja dan disiplin kerja terhadap variabel terikat $(\mathrm{Y})$ yaitu kinerja karyawan.

Ha : $b_{1} \neq b_{2} \neq 0$, artinya secara serentak terdapat pengaruh positif dan signifikan dari variabel bebas $\left(\mathrm{X}_{1}, \mathrm{X}_{2}\right)$ berupa lingkungan kerja dan disiplin kerja terhadap variabel terikat $(\mathrm{Y})$ yaitu kinerja karyawan.

Pada penelitian ini, diketahui jumlah sampel (n) = 39 dan jumlah keseluruhan variabel (k) adalah 3, sehingga diperoleh:

$\mathrm{df}($ pembilang $)=\mathrm{k}-1 \rightarrow 3-1=2$

$\mathrm{df}$ (penyebut) $=\mathrm{n}-\mathrm{k} \rightarrow 39-3=36$

Nilai $F_{\text {hitung }}$ akan diperoleh kemudian akan dibandingkan dengan nilai $\mathrm{F}_{\text {tabel }}$ pada tingkat $\square=5 \%$ $(2 ; 36)=3,26$ dengan kriteria uji sebagai berikut:

Ho diterima bila $\mathrm{F}_{\text {hitung }}<\mathrm{F}_{\text {tabel }}$ pada $\square=5 \%$ Ha diterima bila $\mathrm{F}_{\text {hitung }}>\mathrm{F}_{\text {tabel }}$ pada $\square=5 \%$

Tabel 6. Hasil uji F (Uji Simultan / Serentak)

\begin{tabular}{|c|c|c|c|c|c|}
\hline \multicolumn{6}{|c|}{ ANOVA $^{b}$} \\
\hline Model & $\begin{array}{c}\text { Sum of } \\
\text { Square } \\
\text { s }\end{array}$ & df & $\begin{array}{l}\text { Mean } \\
\text { Square }\end{array}$ & $F$ & Sig. \\
\hline $\begin{array}{ll}1 & \begin{array}{l}\text { Regress } \\
\text { on }\end{array}\end{array}$ & $\begin{array}{r}305.44 \\
7\end{array}$ & 2 & $\begin{array}{r}152.72 \\
3\end{array}$ & 21.235 & $.000^{\circ}$ \\
\hline Residua & $\begin{array}{r}258.91 \\
2\end{array}$ & 36 & 7.192 & & \\
\hline Total & $\begin{array}{r}564.35 \\
9\end{array}$ & 38 & & & \\
\hline
\end{tabular}




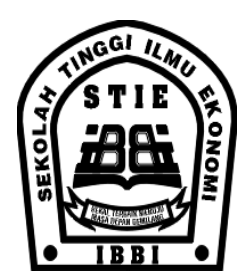

a. Predictors: (Constant), disiplin kerja-total, lingkungan kerja-total

b. Dependent Variable: kinerja-total

Berdasarkan tabel 6. bahwa nilai $\mathrm{F}_{\text {hitung }}$ adalah 21,235 dengan tingkat signifikansi 0,000, sedangkan $\mathrm{F}_{\text {tabel }}$ pada tingkat kepercayaan $95 \%(\square=5 \%)$ adalah 3,26. Dengan demikian bahwa $\mathrm{F}_{\text {hitung }}>\mathrm{F}_{\text {tabel }}$ dan tingkat signifikansi $(\mathrm{p}=0,000<0,05)$, artinya bahwa variabel lingkungan kerja dan disiplin kerja secara serempak atau bersama-sama berpengaruh positif terhadap kinerja karyawan PTPN II Unit Helvetia Medan

\section{d. Uji Signifikansi (uji t)}

Uji t dilakukan untuk menguji secara parsial apakah variabel bebas yang terdiri dari lingkungan kerja dan disiplin kerja berpengaruh signifikan masing-masing terhadap kinerja karyawan PTPN II Unit Helvetia Medan.

Model hipotesis yang akan digunakan adalah sebagai berikut:

Ho: $b_{1}=b_{2}=0$, artinya secara parsial tidak terdapat pengaruh positif dan signifikan dari variabel bebas $\left(\mathrm{X}_{1}, \mathrm{X}_{2}\right)$ berupa lingkungan kerja dan disiplin kerja terhadap variabel terikat (Y) yaitu kinerja karyawan PTPN II Unit Helvetia Medan.

Ha: $b_{1} \neq b_{2} \neq 0$, artinya secara parsial terdapat pengaruh positif dan signifikan dari variabel bebas $\left(\mathrm{X}_{1}, \mathrm{X}_{2}\right)$ berupa lingkungan kerja dan disiplin kerja terhadap variabel terikat (Y) yaitu kinerja karyawan PTPN II Unit Helvetia Medan.

Kriteria pengambilan keputusan yaitu:

Ho diterima bila $\mathrm{t}_{\text {hitung }}<\mathrm{t}_{\text {tabel }}$ pada $\square=5 \%$

Ha diterima bila $t_{\text {hitung }}>t_{\text {tabel }}$ pada $\square=5 \%$

Nilai $t_{\text {hitung }}$ yang diperoleh, kemudian dibandingkan dengan nilai $t_{\text {tabel }}$ pada tingkat kepercayaan $(\square)=5 \%$ yakni yang diperoleh derajat bebas $=\mathrm{df}-\mathrm{k}(\mathrm{df}=$ jumlah sampel dan $\mathrm{k}=$ jumlah variabel keseluruhan) yaitu df $1=3-1=2$, dan df $2=$ $39-3=36$. Uji $t_{\text {hitung }}$ yang dilakukan adalah uji dua arah maka $t_{\text {tabel }}$ yang digunakan adalah $t_{5 \%}$ atau $t_{0,05}$ $(36)=1,688$.
ISSN 1858-3199

JURNAL

MANAJEMEN BISNIS

STIE IBBI

Tabel 7. Hasil uji t (uji Parsial)

Coefficients $^{\mathrm{a}}$

\begin{tabular}{|c|c|c|c|c|c|}
\hline \multirow[b]{2}{*}{ Model } & \multicolumn{2}{|c|}{$\begin{array}{l}\text { Unstandard } \\
\text { ized } \\
\text { Coefficient } \\
\text { s }\end{array}$} & \multirow{2}{*}{$\begin{array}{c}\begin{array}{c}\text { Standard } \\
\text { ized } \\
\text { Coeffici } \\
\text { ents }\end{array} \\
\\
\text { Beta }\end{array}$} & \multirow[b]{2}{*}{$\mathrm{t}$} & \multirow[b]{2}{*}{ Sig. } \\
\hline & B & $\begin{array}{l}\text { Std. } \\
\text { Error }\end{array}$ & & & \\
\hline 1 (Constant) & $\begin{array}{r}.51 \\
8\end{array}$ & 3.373 & & $\begin{array}{r}.15 \\
3\end{array}$ & $\begin{array}{r}.87 \\
9\end{array}$ \\
\hline $\begin{array}{l}\text { lingkunga } \\
\mathrm{n} \text { kerja }\end{array}$ & $\begin{array}{r}.51 \\
1\end{array}$ & .190 & .389 & $\begin{array}{r}2.6 \\
87\end{array}$ & $\begin{array}{r}.01 \\
1\end{array}$ \\
\hline $\begin{array}{l}\text { disiplin } \\
\text { kerja }\end{array}$ & $\begin{array}{r}.46 \\
3\end{array}$ & .157 & .427 & $\begin{array}{r}2.9 \\
47\end{array}$ & $\begin{array}{r}.00 \\
6\end{array}$ \\
\hline
\end{tabular}

a. Dependent Variable: kinerja

Berdasarkan Tabel 7. dapat disimpulkan sebagai berikut:

1) Variabel lingkungan kerja

Nilai $t_{\text {hitung }}$ dari variabel lingkungan kerja adalah 2,687 dengan tingkat signifikan 0,011 dan nilai $\mathrm{t}_{\text {tabel }}$ pada alpha $5 \%$ dan df1 $=36$ adalah 1,688. Variabel lingkungan kerja berpengaruh secara positif dan signifikan terhadap kinerja karyawan PTPN II Unit Helvetia Medan. Nilai $t_{\text {hitung }}$ $(2,687)>t_{\text {tabel }}(1,688)$ artinya jika variabel lingkungan kerja meningkat 1 satuan (unit) maka kinerja karyawan PTPN II Unit Helvetia Medan (Y) akan meningkat sebesar 2,687 satuan.

2) Variabel Disiplin kerja

Nilai $t_{\text {hitung }}$ dari variabel disiplin kerja adalah 2,947 dengan tingkat signifikan 0,006 dan nilai $t_{\text {tabel }}$ pada alpha $5 \%$ dan df $1=36$ adalah 1,688. Variabel disiplin kerja berpengaruh secara positif dan signifikan terhadap kinerja karyawan PTPN II Unit Helvetia Medan. Nilai $t_{\text {hitung }}$ $(2,947)>t_{\text {tabel }}(1,688)$ artinya jika variabel disiplin kerja meningkat 1 satuan (unit) maka 


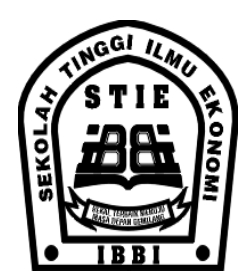

kinerja karyawan PTPN II Unit Helvetia Medan (Y) akan meningkat sebesar 2,947 satuan.

\section{Pembahasan}

\section{Pengaruh Lingkungan Kerja Terhadap Kinerja Karyawan PTPN II Unit Helvetia Medan}

Berdasarkan hasil penelitian menggunakan uji regresi linier berganda pada uji signifikansi (uji t) secara menunjukkan bahwa ada pengaruh signifikan lingkungan kerja dengan kinerja karyawan dengan nilai $t_{\text {hitung }}(2,687)>t_{\text {tabel }}(1,688)$ dan nilai $p=0,011<0,05$. Jika variabel lingkungan kerja meningkat 1 satuan (unit) maka kinerja karyawan PTPN II Unit Helvetia Medan (Y) akan meningkat sebesar 2,687 satuan.

Penelitian Iriani (2012) dengan judul Analisis Pengaruh Kompensasi, Lingkungan Kerja Dan Kepemimpinan Terhadap Kinerja Karyawan Studi Kasus PT. Ungaran Sari Garment unit Ungaran Section Finishing and Packing Departemen Shirt mendapatkan hasil bahwa lingkungan kerja memberikan pengaruh yang signifikan terhadap kinerja karyawan PT. Ungaran Sari Garment, namun pengaruh yang terjadi adalah negatif dengan $t$ hitung sebesar -4.041 dan nilai sig t $0,000<$ alpha 0,05 artinya bahwa lingkungan kerja yang ada selama ini memberikan pengaruh yang berlawanan dimana terdapat persaingan yang kurang sehat antar karyawan dan komunikasi yang kurang baik dengan teknikal yang mengatur mereka, kondisi yang demikian tentu akan membawa dampak yang tidak baik bagi lembaga dalam meningkatkan kinerja karyawan dalam pencapaian tujuan organisasi.

Lingkungan kerja memegang peranan penting dalam organisasi, karena secara tidak langsung dapat mempengaruhi keberhasilan suatu proses produksi. Adanya lingkungan kerja yang baik akan memuaskan bagi karyawan dan menjadi dasar pada peningkatan efektivitas dalam pekerjaan. Hasil ini sekaligus memberikan bukti empiris bahwa lingkungan kerja sebagai salah satu sarana penunjang kerja apabila dibuat dengan penerangan, warna yang tidak membuat lelah, pertukaran udara yang baik, kebisingan yang tidak terlalu besar dan adanya musik yang dapat memberikan semangat kerja dalam hal ini akan memberikan rangsangan

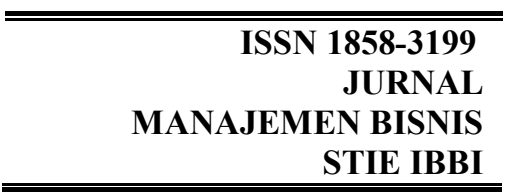

terhadap saraf seseorang untuk bekerja dengan memperkecil tingkat kelelahan mereka. Hal ini akan mendukung terjadinya peningkatan kinerja karyawan (Rusyadi, 2011).

Lingkungan kerja merupakan segala sesuatu yang ada di sekitar para pekerja yang dapat mempengaruhi dirinya dalam menjalankan tugastugas yang dibebankan. Hughes (2007), melakukan survei pada 2000 karyawan dari berbagai macam perusahaan dan industri, melaporkan bahwa sembilan dari tiap sepuluh responden mempercayai bahwa kualitas lingkungan kerja akan mempengaruhi perilaku dari karyawan dan meningkatkan produktivitasnya.

Lingkungan kerja di PT. Perkebunan Nusantara II memberikan pengaruh yang positif pada kinerja karyawan. Lingkungan kerja yang baik meliputi penerangan yang memadai, temperatur atau suhu udara yang membuat karyawan merasa nyaman dalam bekerja, sirkulasi udara sudah baik, ruang kerja jauh dari kebisingan, tata warna ruang kerja selalu terpelihara, dan lingkungan kerja memberikan jaminan keselamatan kerja bagi karyawannya. Dengan adanya fasilitas-fasilitas tersebut akan menyebabkan lingkungan kerja menjadi tempat yang nyaman bagi karyawan dalam bekerja. Lingkungan kerja yang baik dan nyaman akan menimbulkan kepuasan dan meningkatkan kinerja karyawan sehingga karyawan mampu melaksanakan tugastugas sesuai tujuan yang telah ditentukan oleh organisasi.

\section{Pengaruh Disiplin Kerja Terhadap Kinerja Karyawan PTPN II Unit Helvetia Medan}

Berdasarkan hasil penelitian menggunakan uji regresi linier berganda pada uji signifikansi (uji t) secara menunjukkan bahwa ada pengaruh signifikan disiplin kerja dengan kinerja karyawan dengan nilai $\mathrm{t}_{\text {hitung }}(2,947)>\mathrm{t}_{\text {tabel }}(1,688)$ dan nilai $p=0,006<0,05$. Jika variabel disiplin kerja meningkat 1 satuan (unit) maka kinerja karyawan PTPN II Unit Helvetia Medan (Y) akan meningkat sebesar 2,947 satuan.

Sejalan dengan penelitian yang dilakukan Amelia (2009) yang meneliti di PT. Jane Indah Perkasa Cabang Semarang bahwa berdasarkan hasil pengujian menunjukkan bahwa pengaruh disiplin 


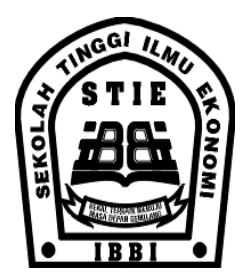

kerja terhadap kinerja karyawan adalah positif signifikan hal ini terbukti dengan nilai $\mathrm{t}$ hitung sebesar 3,016 > t tabel yaitu 2,000. Pengukuran variabel kedisiplinan didasarkan pada aspek mengikuti peraturan yang ada hampir lebih dari $60 \%$ menunjukkan bahwa semua pegawai harus mengikuti peraturan yang ada, sedangkan didasarkan pada aspek menjaga kuantitas pekerja semua responden menunjukkan bahwa ingin meningkatkan kuantitas dalam bekerja, pada aspek mendapatkan reward atau kompensasi ada sebagian kecil responden tidak senang atas adanya kompensasi yang diberikan, dan melakukan hal-hal yang positif responden hampir semua melakukan hal tersebut dalam mendukung kinerja mereka di perusahaan.

Hasibuan (2004) berpendapat bahwa kedisiplinan adalah kesadaran dan kesediaan seseorang menaati semua peraturan perusahaan dan norma-norma sosial yang berlaku. Menurut Terry dalam Sutrisno (2010), disiplin merupakan alat penggerak karyawan. Agar tiap pekerjaan dapat berjalan dengan lancar, maka harus diusahakan agar ada disiplin yang baik. Disiplin tidak hanya dihubungkan dengan hal-hal yang kurang menyenangkan (hukuman) karena sebenarnya hukuman merupakan alat paling akhir untuk menegakkan disiplin.

Pengukuran disiplin kerja dalam penelitian ini mengacu kepada absensi atau kehadiran, ketaatan pada kewajiban tugas dan peraturan, serta bekerja sesuai prosedur. Karyawan PT. Perkebunan Nusantara II Unit Helvetia Medan menyatakan selalu hadir di kantor dan pulang tepat pada waktunya, karyawan mentaati atau mengikuti instruksi kerja yang diberikan pimpinan serta bertanggungjawab terhadap pekerjaan yang diemban. Karyawan berusaha mengikuti prosedur kerja yang ditetapkan perusahaan, dan juga menciptakan suasana kerja yang baik dalam perusahaan. Upaya-upaya tersebut merupakan indikator terciptanya disiplin kerja bagi para karyawan.

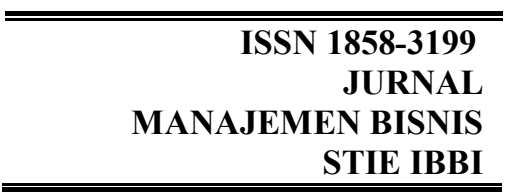

\section{KESIMPULAN}

1. Lingkungan kerja berpengaruh positif terhadap kinerja karyawan PT. Perkebunan Nusantara II Unit Helvetia Medan, $t_{\text {hitung }}(2,687)>t_{\text {tabel }}$ $(1,688)$ dan nilai $p=0,011<0,05$. Semakin baik lingkungan kerja maka akan semakin meningkat pula kinerja karyawan.

2. Disiplin kerja berpengaruh positif terhadap kinerja karyawan PT. Perkebunan Nusantara II Unit Helvetia Medan, $t_{\text {hitung }}(2,947)>t_{\text {tabel }}$ $(1,688)$ dan nilai $p=0,006<0,05$. Semakin baik disiplin kerja karyawan maka akan semakin meningkat pula kinerja karyawan.

3. Variabel lingkungan kerja dan disiplin kerja dapat menjelaskan kinerja karyawan sebesar $54,1 \%$, sedangkan sisanya sebesar $45,9 \%$ dipengaruhi oleh variabel lain yang tidak diteliti dalam penelitian ini seperti gaya kepemimpinan, supervisi, motivasi, kompensasi, dan lain-lain.

\section{REFERENSI}

Amelia, E. 2009. Pengaruh Motivasi Kerja Dan Kedisiplinan Terhadap Kinerja Pegawai PT. Jane Indah Perkasa Cabang Semarang. Universitas Semarang

Dharmawan, I Made Yusa. 2011. Pengaruh Kompensasi dan Lingkungan Kerja Non Fisik Terhadap Disiplin dan Kinerja Karyawan Hotel Nikki Denpasar. Denpasar : Program Pascasarjana Universitas Udayana.

Fathoni, Abdurrahmat. 2006. Manajemen Sumber Daya Manusia. Jakarta : PT. Rineka Cipta.

Hughes, J. 2007. Office Design in Pivotal to Employee Productivity. Sandiego: The Daily Transcript.

Iriani, E.S. 2012. Analisis Pengaruh Kompensasi, Lingkungan Kerja Dan Kepemimpinan Terhadap Kinerja Karyawan Studi Kasus PT. Ungaran Sari Garment unit Ungaran Section Finishing and Packing Departemen Shirt. Fakultas Ekonomi Universitas Semarang. 


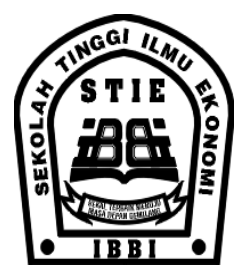

ISSN 1858-3199

Kaswan. 2012. Manajemen Sumber Daya Manusia Untuk Keunggulan Bersaing Organisasi. Yogyakarta : Graha Ilmu.

Nawawi, H. 2003. Perencanaan SDM Untuk Organisasi Profit yang Kompetitif. Yogyakarta : Gadjah Mada University Press.

Nitisemito, A. 2002. Manajemen Personalia. Jakarta : Ghalia Indonesia.

Prawatya, D.A. 2012. Skripsi Pengaruh Disiplin Kerja dan Budaya Organisasi Terhadap Kinerja Karyawan Pabrik Minyak Kayu Putih (PMKP) di Krai Purwodadi. Semarang : Fakultas Ekonomi Universitas Diponegoro.

Riani, A.L. 2011. Budaya Organisasi. Yogyakarta : Graha Ilmu.

Rusyadi, M.A., dan Pahlawansjah Harahap. 2011. Pengaruh Kepemimpinan, Motivasi Dan Lingkungan Kerja Terhadap Kinerja Karyawan (Studi Kasus Di PT. Best Semarang). Fakultas Ekonomi Universitas Semarang

Sedarmayanti. 2009. Tata Kerja dan Produktivitas Kerja : Suatu Tinjauan dari Aspek Ergonomi atau Kaitan Antara Manusia Dengan Lingkungan Kerjanya. Bandung : CV. Mandar Maju.

Sutrisno, Edy. 2010. Manajemen Sumber Daya Manusia. Jakarta : Kencana.

Wursanto. 2005. Dasar-dasar Ilmu Organi-sasi. Yogyakarta : ANDI. 